\title{
Social and Health Care Access for the Physically Disabled in 19th Century French-Speaking Switzerland: A Double Process of Exclusion and Integration
}

\author{
Mariama Kaba
}

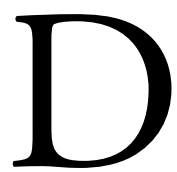
uring the 19th century, an unprecedented process of medicalisation and institutionalisation unfolded in Europe. At the beginning and at the end of the century, respectively, the medical upheavals of anatomoclinic and microbiology had a major influence on the organisation of hospitals and medical studies. Cantonal hospitals, rapidly linked to medical faculties, were created in Switzerland in the second half of the century, and by 1874, the first federal medical exams took place, implying a standardisation of requirements at a national level. The parallel development of urbanised and industrialised areas furthered the densification of a network of care institutions such as infirmaries and dispensaries, whilst medical tourism was developed among the upper classes stimulating the founding of new private clinics.

During that time, a more institutional kind of care structure for people with disabilities also emerged. This medical and/or social care structure was part of a process of integration or exclusion, according to whether the disabled person's state of health was likely to improve or, to the contrary, to become permanent. According to contemporary medical classification, there were numerous kinds of disability, ranging from the mechanical (amputees and cripples; those with fractures; the deformed, hump-backed, lame, ankylosed or paralyzed) to the sensorial (the blind, the deaf-and-dumb) and to curable or incurable diseases (scrofula, epilepsy, cancer). This paper will essentially focus on physically disabled persons, i.e. disabled workers, elderly invalids, the chronically or congenitally sick all of whom were vaguely referred to as invalids or the "incurable" (in French: invalides, infirmes, incurables) in 19th century institutional documents. Being mainly interested in French-speaking Switzerland, I will present the access to social and health care in the cantons of Geneva, Vaud and Neuchâtel. 


\section{Poverty as a Factor in the Social Care of the Disabled}

Looking at the history of the social and medical care of the disabled in the 19th century, one notices that this concerns first and foremost the history of the poorest social class. Rather, a disability only became visible in so far as it drove the person concerned to a state of such indigence that outside help became necessary. In addition to those without means, a large number of the physically disabled who became socially dependant belonged to the class just above the poverty-line. This mainly meant small-scale farmers, farm-workers, and artisans who, because they only just made a living from their work, were the most vulnerable in the event of an unforeseen accident. As of the second half of the century, this class was to grow to include urban workers and servants, as the process of urbanisation and industrialisation became a major factor in the emergence of new cases of disability among an ever-increasing population. Yet being handicapped did not automatically entitle anyone to aid: support was determined according to each person's circumstances. Not until late in the century did disability as such attract the attention already given to poverty by private philanthropy or public welfare.

In Geneva (legally) organized aid was provided by the General Hospital (or the Hospice). Set up in the 16th century by the city authorities, it was responsible for the administration of almost all charity for the sick and the poor. In the beginning of 19th century, when Geneva became a Swiss canton, the communes were also supposed to assist their poor but most of these did not receive enough and resorted to the General Hospital as well. Now this was more a welfare institution than a place for nursing the sick. For the disabled who applied there - along with the elderly or young orphans - the usual practice was "farming out", that is to say, placing them as subsidized lodgers in some country household, while the General Hospital provided the necessary clothing and medical aid, and made official visits ${ }^{1}$. In the canton of Vaud, in 1850, the authorities founded the Cantonal Institution for elderly invalids and the "incurable"; the main activity of the institution was to place such people in private homes or care for them at home ${ }^{2}$. At the same time, there were around 500 sick poor in the canton of Neuchâtel, most of them with chronic diseases or mental deficiencies. Two-thirds of these were cared for by their own families and nearly 200 "farmed out" to live in miserable conditions ${ }^{3}$. In the town of Neuchâtel, a Committee for the Incurable financed the placing of such unfortunates in families as of 1854 . One can see here how willing the authorities

1 Pierre Bertrand, "Les hôpitaux de Genève à travers les siècles", Centième anniversaire de l'Hôpital cantonal de Genève 1856-1956 (Genève, 1956), pp. 17-38; Rapports annuels et comptes rendus sur l'Hôpital, 1840-1850's.

2 Victor Segond, La bienfaisance dans le canton de Vaud (Nyon, 1895), pp. 125-126.

3 Charles Thomann, L'art de guérir au XIXe siècle en pays neuchâtelois (La Chaux-deFonds, 1995), pp. 114-115. 
were to remove the "unproductive" from urban centres already overcrowded with workers ${ }^{4}$.

There is no doubt that in the first half of the 19th century such "farming out" was deemed preferable to building specialized institutions. This system saved the authorities the expense of building such facilities. Furthermore, contemporary society was against aid being made too easy, on account of the moral prejudice to both private charity and the family: the two mainstays of such health care in the 19th century. According to a then dominant liberal ideology, public responsibility for the disabled should not extend beyond the working-class poor, namely those who generally had no property or goods to bequeath and ought not to be left to themselves for fear that they might turn to begging or vagrancy, and become a real "public problem"s. It should however be noted that most of those who resorted to assistance were locals (droit de bourgeoisie) and thus entitled to aid. In the case of other, less stable populations (vagrants not belonging to any commune - "foreigners"), access to aid was always problematic and any financial help they did receive was usually next to nothing ${ }^{4}$.

\section{(Self-)Exclusion from Health Care Structures}

As far as any medical care required by the disabled was concerned, this was in part delivered to in their own homes and, in the case of the most destitute, free of charge. They had, however, to be within reach of a doctor, which usually meant not far from a town. It was also in town that a large number of chronically sick or the "incurable" poor spent considerable time in health care institutions. However, during the first half of the 19th century, such care meant setting up the kind of infrastructures which rural areas - ill-equipped and with little centralized power could not afford. In the canton of Vaud, for example, there were hardly any hospitals or hospices outside of the main town Lausanne until the $1850 \mathrm{~s}^{5}$. Transporting a sick person was a serious problem in itself. In the 1830s local insurance companies sometimes required trade masters to have their sick workers nursed at home ${ }^{6}$. How-

4 This removal of the disabled poor was also justified by the feelings of repulsion and disgust aroused in the general public. It is indeed difficult to speak of disability in the 19th century without recalling the "monster" legacy (teratology) from the previous century. However, the vast subject of socio-cultural attitudes to physical handicap cannot be discussed here.

5 Nicolas Nussbaum, "Les asiles de vieillards genevois au XIXe siècle", Bulletin du département d'histoire économique, 19 (1988-1989), pp. 41-54.

4 Anne-Lise Head, "Au dossier de la pauvreté: Réflexions sur la politique d'encadrement' des pauvres dans les villes et les campagnes suisses (XVIe-XIXe siècles)", Bulletin du département d'histoire économique, 19 (1988-1989), pp. 31-39.

5 This date coincides with the creation of the modern Federal State (1848). This, together with industrialisation, probably accounts for the increase in the number of health care facilities from then on.

6 Françoise Nicod, "Le souci de l'utilité publique dans le canton de Vaud dans la première moitié du XIXe siècle", Revue historique vaudoise, 90 (1982), pp. 81-147. 
ever, small farmers or self-employed artisans - which, in the first half of the 19th century meant most of the population - had no choice but to seek care in town.

Moreover there is the question of the risk involved in clinical treatment. As far as many people were concerned, this not only aroused fear and mistrust but also often involved financial hardship. Workers were reluctant to stop earning their living for treatment which was often required to be lengthy to have any effect. The victim of an accident may have had trouble understanding why a particular treatment worked so well in some cases and was taking so long in others. However, even a minor fracture if not properly healed could lead to complications such as paralysis of the limb involved. Injuries sustained by field or other workers, mostly on the legs, soon became ulcerous in the absence of proper treatment; this could happen all the more easily in situations of poor diet and difficult working conditions. In the city of Geneva, at the Dispensary for the Poor founded by four doctors in 1820, more than $60 \%$ of the patients left before being discharged, in some cases after only one visit ${ }^{7}$. This situation was to change as of the middle of the century. Industrialisation began to have a direct impact on public health and medical practice. With so many workers in one place, mechanisation of the means of production and the implementation of major infrastructures, the number of sick and injured rose out of all proportion compared with that of traditional, rural populations. In Switzerland the first statistics, not gathered before 1876, show that during the last third of the century men had 3-4 times more accidents, fatal or not, of all kinds, than women (injuries sustained in accidents caused by vehicles, horses or machinery, falls, landslides, firearms, etc. $)^{8}$. Among Swiss workers the most frequent injuries were to hands or feet: $72 \%$ of the total number of injuries recorded". Taking their cue mainly from philanthropy, with foresight as their watch-word, mutual aid societies (insurances) came into being. This movement accompanied the development of medical infrastructures and wider access to health care.

Likewise, with the ever-increasing number of lines being laid, and railway companies having to take responsibility for the loss of human life or limb, not only did existing health care facilities develop accordingly but new local infirmaries were opened to deal with the growing number of accidents ${ }^{10}$. At the very end of the century, new surgical techniques appeared in hospitals, along with radiology. These new techniques were for critical cases where treatment required first-class medical performance but limited bed occupation, with the patient being cured and dis-

7 Rapports du Dispensaire de Genève, 1830's.

8 Hansjörg Siegenthaler (dir.), Heiner Ritzmann-Blickenstorfer (éd.), Statistique historique de la Suisse (Zurich, 1996), p. 344. At the end of the 20th century, among the causes of invalidity accidents still represented the greatest difference between the sexes: $6 \%$ in the case of women against 13\% men. (Walter Weiss (dir.), La santé en Suisse (Lausanne, 1993), p. 87).

9 "Statistique des lésions corporelles et des morts violentes survenues chez les membres de caisses suisses de secours mutuels de 1886-1888, incl. Publication du secrétariat ouvrier Suisse" (Winterthour, 1891); cited in the bibliography of the Revue médicale de la Suisse romande, 7 (1891), pp. 434-435.

10 Pierre-Yves Donzé, "L'impact de la construction des chemins de fer sur la médecine hospitalière en Suisse romande, 1850-1914", Cahiers de l'AEHMO, 20 (2004), pp. 34-46. 
charged as quickly as possible. For that reason, the incurable elderly, the chronically sick, the disabled, etc. - who up until then had been looked after in hospitals and infirmaries - were in need of new accommodation. "In such cases", noted a Genevese philanthropist of the time, "it is not a question of finding the means to cure them but to make it easier for them to lead a life dependant on public or private charity in the most suitable and economical way." ${ }^{11}$

The situation of the disabled from the wealthy classes was quite different. Most were cared for privately at the family's expense. As a few examples show, the welloff could be treated in their own homes and, depending on the family environment, remain socially integrated. One noteworthy case is that of Aimée Rapin (1868-1956), an artist born without arms into a wealthy family of Payerne (Vaud), who was to paint, using her feet, the portrait of several famous Europeans ${ }^{12}$. In any event, until late in the century the rich refused to have their sick treated in institutions primarily intended for the poor. They considered having to resort to such places, where people were shut in with no privacy, as shameful or socially demeaning. Towards the end of the century, the growing number of private clinics meant that the rich could be cared for in these new institutions, depending on the nature of the treatment required, more easily than in their own homes.

\section{Institutionalisation of Care for the Disabled}

In the last third of the 19th century, after the limits of the "farming out" of disabled persons had been recognized and the practice gradually given up in Switzerland (although it remained in use until the mid 20th century for abandoned children and those taken away from their parents), a process of institutionalisation of aid ensued on an unprecedented scale. In 1875, in the canton of Vaud, the first hospice for incurable women was opened. It also took in a few children as of 1890 , while the asylum for the incurable elderly of the village of Château-d'Oex was already receiving patients in $1880^{13}$. Not until 1891 , however, did the canton of Neuchâtel decide to found a cantonal hospice for the incurable, which was to be opened six years later in Perreux, a little town in the Jura region of Neuchâtel ${ }^{14}$. Once again, one can gather from the geographical location of such institutions that the idea was to send the disabled away from the towns.

11 "Rapport sur les travaux de la Société pendant l'année 1869, lu par G. Moynier", Société genevoise d'utilité publique (1869), p. 96.

12 See Simone Rapin, A propos d'Aimée Rapin, peintre sans bras (Payerne, 1996). See also the reality-based fiction on a young disabled aristocrat living in Neuchâtel at the end of the century, analyzed in Mariama Kaba, “' 6 mai 1868. J'essaie d'écrire'. Aventures et énigmes autour du journal intime d'un jeune handicapé”, in Mauro Cerutti, Jean-François Fayet, Michel Porret (dir.), Penser l'archive: histoires d'archives - archives d'histoire (Lausanne 2006), pp. 131-145.

13 Victor Segond, La bienfaisance dans le canton de Vaud, pp. 130-131.

14 Charles Thomann, L'art de guérir au XIXe siècle en pays neuchâtelois, pp. 114-115. 
This was also the case in Geneva. The Cantonal Hospital, built in 1856 in the middle of the canton and very close to the town, took in mainly medical and surgical cases and gradually came to refuse the chronically or mentally ill. It was in order to make more beds available at the Hospital that the authorities created, at the end of the century, the Asylum of Loëx, for the chronically or incurably ill, as well as the Mental Asylum. These two institutions were located in the Genevese countryside. The care offered by them consisted of no more than providing healthy conditions and proper food, for the inmates to live as best they could. That is why the Asylum of Loëx - already planned in 1876 but not opened until 1899 - had only a limited medical staff (one doctor and two nurses) to carry out check-ups and provide basic treatment. In its first year, however, the Asylum took in around thirty patients, the majority of which were hemiplegics, as well as cases of chronic alcoholism, disability, rheumatism, chronic bronchitis, poor sight, heart complaints and ulcers $^{15}$. The cantonal authorities arranged for outpatient medical aid to be provided in the urban area by the University's polyclinic and, in the communes and elsewhere in the canton, by local doctors. The disabled stayed at home or were interned, with priority always being given to the needy.

The end of the 19th century saw a great increase in the number of institutions for the physically disabled, subsidized mainly by the public authorities. This was however a mixed blessing: the disabled did indeed benefit from a system of care specially adapted to their needs but, shut in behind institutional walls and kept out of sight of the able-bodied, they were completely cut off from society. Such exclusion through isolation or institutionalisation was society's response to fear of crime and begging traditionally associated with all social misfits - including the disabled. This also had to do with a new ideology which arose in the 1880s and at the end of the century had become widespread among European states, including Switzerland: fear of "degeneration of the race", which in turn originated in social Darwinism and eugenics. A bodily malformation was no longer considered to occur by accident but was attributed to a general weakening of the human species. The latter had therefore to be regenerated according to health principles laid down by doctors who, as part of the public establishment, were to be the guardians of public health for future generations. That is why, along with social exclusion of the less fortunate, preventive measures began to emerge, and be put in practice through intermediary of that modern institution, the state school.

\section{Exclusion from School and Medical Initiative for Disabled Children}

Indeed, from the middle of the 19th century onwards, European nations were opening state schools for the education of all social classes. State control over the

15 Armand Brulhart, Loëx. L'Asile, la Maison, l'Hôpital dans la presqu'̂̀le (Genève, 2000), pp. 34-43. 
behaviour and development of future "citizens" was thus obtained through the intermediary of the teaching profession and school visits by medical staff becoming obligatory at the end of the century. With the State anxious to have the established order respected, which from then on was to be maintained by keeping a close watch on bodies ${ }^{16}$, doctors developed systems of classification which led to the most seriously disabled being branded as deviant and expelled from the school system. Until the end of the century, when the question of special classes was raised for the first time (which in any case were only to cater for children considered to be the least mentally retarded), pupils who were physically or intellectually incapable of attending lessons were exempted from compulsory education. In the canton of Geneva, for example, according to the General Primary School Regulation of 1888 (of which the one of 1848 was the precursor) no children classified as idiots, deafand-dumb, blind or affected by any contagious or repulsive disease were allowed to attend school: they could be taken care of in specialized institutions ${ }^{17}$.

Children physically disabled from a very early age were the object of particularly close medical attention. It was in fact in Orbe, a little village in the canton of Vaud, that the very first orthopaedic institution for children with malformations was founded in 1780 by Jean-André Venel. He advocated non-surgical methods and was particularly renowned for treating club feet with the aid of a special shoe which was named after him (sabot de Venel). He also improved traction beds for spinal deviations. Generations of doctors then succeeded one another at the head of this family institution until the opening in 1876 of the French-speaking Switzerland Orthopaedic Hospital. It was founded in Lausanne by the Genevese doctor Henry Martin and, upon a background of Protestant philanthropy, financed from private sources in the cantons of Vaud and Geneva. From then on, a network of doctors dedicated to the treatment of disabled children - free of charge for the poorest was developed. Thus the doctor Edward Martin, cousin of Henry Martin, was also taking in young cripples at the Plainpalais Home for Sick Children in Geneva which he had been in charge of since 1886; in 1899 he founded the orthopaedic clinic of Pinchat for children with congenitally acquired malformations (club foot, dislocations, rickets, infantile paralysis) and bone-and-joint TB (Pott's disease, hip disease, white knee tumour $)^{18}$.

Orthopaedics is a typical example of the 19th century medicalisation process, in relation to physical disability. In the canton of Vaud, where the Orthopaedics Hospice for French-speaking Switzerland was located, a specific orthopaedic exam

16 See Michel Foucault, Surveiller et punir: naissance de la prison (Paris, 1975); Mariama Kaba, "La scoliose entre maladie scolaire et pathologie féminine: un débat opposant hygiénistes et orthopédistes au sujet du corps des filles et des garçons (fin XIXe-début XXe siècles)", Le Détour, 5 (2005).

17 Martine Ruchat, Inventer les arriérés pour créer l'intelligence. L'arriéré scolaire et la classe spéciale. Histoire d'un concept et d'une innovation psychopédagogique. 1874-1914 (Bern, 2003), p. 23.

18 Edouard Martin, Alfred Machard, Asile de Pinchat 1899-1924, [Genève, 1925]. 
organized by the Health Council of Lausanne had existed since 1850. It had to do with various medical and technical issues: anatomy and physiology of locomotion organs, orthopaedic means - mechanical or not - used for the limbs and the straightening of the spine, shoulders and pelvis, and hygienic means for their use. However, it was only after 1896 that a university teaching of orthopaedics was set up, because of the lukewarm interest of doctors for a profession considered as a less prestigious annex to surgery ${ }^{19}$. The professional recognition of the field is probably rooted in the concern for future generations which emerged at the end of the century in western countries, as well as in the search for a less invasive form of medicine to treat the physical disabilities of children. Moreover, as the medical market was becoming ever more attractive, orthopaedics also offered a new outlet for doctors interested in drawing in a new, or at least up to then neglected, clientele.

Thus, thanks to initiatives taken by influential, individual doctors, physically disabled children were no longer systematically considered "incurables" but could aspire to be full-fledged citizens and able-bodied workers. From then on they benefited from the latest surgical and orthopaedic methods along with heliotherapy, exposure to pure air and healthy living conditions. These treatments, at first particularly aimed to cure infantile pathologies, soon came to be adapted to adults as well. However, by their very nature such treatments often meant that growing children had to stay in hospital for several months, years even, in order to benefit fully from the therapy ${ }^{20}$. There still remained, therefore, the question of the future social integration of these children, who had had no formal education - a need which was not to be met until the next century.

\section{Conclusion}

Recognition for the disabled came in conjunction with two phenomena reaching their culmination at the end of the 19th century: the medicalisation of society and the gradual adoption of social policies by European states. More and more categories of physical disability were to be defined as the number of institutions and specialisations grew. This was accompanied by the growth of State intervention in all social fields, with private institutions, including those for the disabled, subsidized by the Swiss authorities, and the provision of legal protection for workers (the Factory Law of 1877 and the Illness \& Accident Insurance in 1889).

Nevertheless, throughout the 19th century, social and health care access for the physically disabled remained dependent of private and sporadic public initiatives, which varied rather widely from canton to canton. The main beneficiaries of such care, generally from the most disfavoured classes of society, had no decisional power

19 Michel Gross, Placide Nicod. Un pionnier de l'orthopédie moderne (Yens-sur-Morges 1993), pp. 31-33.

20 Asile de Pinchat: Registre des enfants malades (1899-1922) and Registre des pensionnaires (1899-1943), Archives d'Etat de Genève, AP 39.1, 39.2. 
over their fate, and could but endure situations of exclusion such as "farming out" and institutionalisation at the periphery of social life. In parallel, the expansion of care practices, such as orthopaedics, meant to further the insertion of disabled children, as well as that of adults in the workplace, answered the new social and economic requirements of a society on the path of industrialisation; thus proving, if need be, that the perception of disability is not only determined by the physical or psychical limitations of the individual, but rests in great part on the way society addresses the question of alterity.

Mariama Kaba, MAS, is Professor at the Haute école de travail social et de la santé - EESP - Vaud, Lausanne, Switzerland. E-mail address: mkaba@eesp.ch or mariama.kaba@unil.ch.

\section{Acknowledgement}

This paper was elaborated on the basis of the research in progress for my doctoral thesis about the history of disability. The theme was inspired by the conference "International Workshop on Health Policies and Social Integration/Exclusion", organized on March 4th-5th 2005 by the National Research Program 51 "Social Integration and Social Exclusion" of the Swiss National Science Foundation, the Phoenix TN, the Department of Community Medicine and Health and the Institute for the History of Medicine and Health of the University of Geneva. 


\section{References}

Asile de Pinchat: Registre des enfants malades (1899-1922), Archives d'Etat de Genève, AP 39.1.

Asile de Pinchat: Registre des pensionnaires (1899-1943), Archives d'Etat de Genève, AP 39.2.

Bertrand, Pierre, "Les hôpitaux de Genève à travers les siècles", pp. 17-38 in Centième anniversaire de l'Hôpital cantonal de Genève 1856-1956. Genève, 1956.

Brulhart, Armand, Loëx. L'Asile, la Maison, l'Hôpital dans la presqu'̂̀le. Genève, 2000.

Donzé, Pierre-Yves, "L'impact de la construction des chemins de fer sur la médecine hospitalière en Suisse romande, 1850-1914", Cahiers de l'AEHMO 20 (2004), 34-46.

Foucault, Michel, Surveiller et punir: naissance de la prison. Paris, 1975.

Gross, Michel, Placide Nicod. Un pionnier de l'orthopédie moderne. Yens-sur-Morges 1993.

Head, Anne-Lise, "Au dossier de la pauvreté: Réflexions sur la politique d'encadrement' des pauvres dans les villes et les campagnes suisses (XVIeXIXe siècles)", Bulletin du département d'histoire économique 19 (1988-1989), 31-39.

Kaba, Mariama, "'6 mai 1868. J'essaie d'écrire'. Aventures et énigmes autour du journal intime d'un jeune handicapé”, pp. 131-145 in Mauro Cerutti, JeanFrançois Fayet, Michel Porret (dir.), Penser l'archive: histoires d'archives archives d'histoire. Lausanne 2006.

Kaba, Mariama, "La scoliose entre maladie scolaire et pathologie féminine: un débat opposant hygiénistes et orthopédistes au sujet du corps des filles et des garçons (fin XIXe- début XXe siècles)", Le Détour 5 (2005).

Martin, Edouard \& Alfred Machard, Asile de Pinchat 1899-1924. [Genève, 1925].

Nicod, Françoise, "Le souci de l'utilité publique dans le canton de Vaud dans la première moitié du XIXe siècle", Revue historique vaudoise 90 (1982), 81-147.

Nussbaum, Nicolas, "Les asiles de vieillards genevois au XIXe siècle", Bulletin du département d'histoire économique 19 (1988-1989), 41-54.

Rapin, Simone, A propos d'Aimée Rapin, peintre sans bras. Payerne, 1996.

Rapports annuels et comptes rendus sur l'Hôpital, 1840-1850's.

Rapports du Dispensaire de Genève, 1830's.

"Rapport sur les travaux de la Société pendant l'année 1869, lu par G. Moynier", Société genevoise d'utilité publique (1869), 94-99. 
Ruchat, Martine, Inventer les arriérés pour créer l'intelligence. L'arriéré scolaire et la classe spéciale. Histoire d'un concept et d'une innovation psychopédagogique. 1874-1914. Bern, 2003.

Segond, Victor, La bienfaisance dans le canton de Vaud. Nyon, 1895.

Siegenthaler, Hansjörg (dir.) \& Heiner Ritzmann-Blickenstorfer (éd.), Statistique historique de la Suisse. Zurich, 1996.

"Statistique des lésions corporelles et des morts violentes survenues chez les membres de caisses suisses de secours mutuels de 1886-1888, incl. Publication du secrétariat ouvrier suisse" (Winterthour, 1891), cited in the bibliography of the Revue médicale de la Suisse romande 7 (1891), 434-435.

Thomann, Charles, L'art de guérir au XIX' siècle en pays neuchâtelois. La Chaux-deFonds, 1995.

Weiss, Walter (dir.), La santé en Suisse. Lausanne, 1993. 